\title{
Mediation as an Alternative Method of Dispute Resolution in Business
}

\author{
Lyubov M. Dzyuba ${ }^{1}$, Nataliia V. Fedorenko ${ }^{2}$, Julia V. Fedorenko ${ }^{3}$
}

\begin{abstract}
:
The article is devoted to the study of mediation as an alternative way to resolve pores in business. The principles and the advantages of mediation as well as the technological intermediaries in practice for the resolution of entrepreneurship and conflicts are analyzed.

The authors have developed a model of mediation and proposed legal means that allow in practice to use mediation in the resolution of pores in business.
\end{abstract}

Keywords: mediation, dispute, business, entrepreneurship, conflict, methods of dispute resolution.

\footnotetext{
${ }^{1}$ Senior lecturer of Civil Law, Law Faculty of Rostov State University (RINH), e-mail: dzuba017@mail.ru

${ }^{2}$ D. SOC.N., Professor, Head. The Civil Procedure Department of the Law Faculty of Rostov State University (RINH), e-mail: fedorenko_vladim@mail.ru

${ }^{3}$ Candidate of legal Sciences, Associate Professor of Civil Law, Law Faculty of Rostov State University (RINH),e-mail: fedorenko_vladim@mail.ru
} 


\section{Introduction}

Mediation is a voluntary way of resolving conflicts through negotiations between parties to a dispute under the guidance of a neutral person. The mediator's task is to help the conflicting parties to find a mutually beneficial compromise. The decision to resolve the conflict is made by the parties to the dispute, using the experience and the knowledge of the mediator. Most disputes involving the mediator end with reconciliation and the conclusion of a mediation agreement on terms mutually beneficial to the parties. Mediation allows individuals, groups and organizations the easiest, most comfortable and convenient way to realize their interests, needs and goals (Romanova, 2017; Emelkina, 2016).

Currently, business needs efficiency and new effective methods of dispute resolution, which could maintain business relations with customers and partners. The current state of the Russian judicial system is a risk for the parties to a commercial dispute, so the parties to the dispute have a need to control the outcome of the dispute. In order to maintain business relations, the parties in dispute must be willing to settle the dispute through an intermediary.

\section{Literature review}

The main sources that reveal the theoretical foundations of business mediation in this article are by Allahverdovoy O.V., Korobkina A.V., Maslennikova L.V., Telesheva, J.A., Yakovlev V.F., Shabalina E.A., Crossan A., Shvabauer, N., Kutsch, E., Menkel-Meadow C., Folberg, J., Harkley, M. and Wheeler, H.M.

International experience of mediation in the business sphere is considered on the basis of A. Trossen "Mediation has become a real alternative to the judicial process", N. Schwabauer "Agree in a good way", E. Kutch "Mediation displaces litigation”, C. Menkel-Meadow "Ten years is just the beginning”, J. Folberg "Mediation changed the legal culture", M. Hackley "Mediation Skills are useful for everyone" and M. Wheeler "Success generates success".

The main confirmation of fixing in business mediation at the legislative level is the Federal law on an alternative procedure of settlement of disputes with participation of the intermediary (mediation procedure). In this article the authors also refer to normative legal acts, such as the civil procedural code of the Russian Federation, the Arbitration procedural code of the Russian Federation.

\section{Method of research}

When studying the essence of mediation, it is necessary to find out a sufficiently significant question whether it should include norms on mandatory compliance with the requirements of the legislation of the Russian Federation, if the parties aim to approve subsequently reached agreements in court, giving them the form of a 
settlement agreement (Maslennikova and Telesheva, 2017). The authors believe that business mediation should be applied in such areas as:

$\checkmark$ Disputes with permanent and other significant business partners (customers, contractors, buyers, suppliers), i.e. if the parties are interested in continuing cooperation and it is important for them to maintain commercial relations.

$\checkmark$ Internal disputes in which personal relations of the parties to the conflict play an essential role: - conflicts between shareholders (participants) of the company; - conflicts between top managers (participants) of the company; disputes on division of the company or withdrawal of the shareholder (participant) out of business.

$\checkmark$ Disputes related to copyright and intellectual property.

$\checkmark$ Conflicts with possible competitors.

$\checkmark$ Collective labour dispute.

As noted in the generalization of the Supreme Court of the Russian Federation on the practice of the courts of the Law, the parties themselves rarely decide to appeal to the mediation procedure. And only after the judge explains to them the essence of this institution, the procedure procedures and advantages give consent to the use of mediation (Certificate of practice of application by Courts of the Federal Law, 2010).

Consider the examples of Table 1 presenting the development of mediation practices in business and ways to solve problems.

Table 1. Mediation problems and results

\begin{tabular}{|l|l|l|}
\hline \multicolumn{1}{|c|}{ problem } & \multicolumn{1}{c|}{ problem solution } & \multicolumn{1}{c|}{ result } \\
\hline $\begin{array}{l}\text { 1. Limited } \\
\text { initiating the } \\
\text { mediation process, } \\
\text { what teaching } \\
\text { caused by the } \\
\text { procedural } \\
\text { legislation } \\
\text { (Bulletin of the }\end{array}$ & $\begin{array}{l}\text { A clear description of the court's } \\
\text { actions to initiate business mediation } \\
\text { and other areas of business. Giving } \\
\text { the court the statutory authority to } \\
\text { initiate mediation. }\end{array}$ & $\begin{array}{l}\text { Reducing the need for } \\
\text { right further promote the } \\
\text { use of mediation by the } \\
\text { inclusion of certain } \\
\text { provisions on mediation in } \\
\text { the norms of substantive } \\
\text { mediation, 2013). }\end{array}$ \\
\hline $\begin{array}{l}\text { 2. The law on } \\
\text { mediation and } \\
\text { procedural law do } \\
\text { not contain any } \\
\text { significant wording } \\
\text { that would provide } \\
\text { for the } \\
\text { impossibility of } \\
\text { bringing a claim }\end{array}$ & $\begin{array}{l}\text { Presidium of the Supreme } \\
\text { Court of the Russian } \\
\text { Federation, 2017). }\end{array}$ \\
\hline
\end{tabular}




\begin{tabular}{|c|c|c|}
\hline $\begin{array}{l}\text { for consideration, } \\
\text { if the parties have } \\
\text { identified the } \\
\text { media as a } \\
\text { mandatory pre-trial } \\
\text { settlement of } \\
\text { disputes by the } \\
\text { Treaty. }\end{array}$ & $\begin{array}{l}\text { the pre-trial dispute settlement } \\
\text { procedure (Bulletin of the Federal } \\
\text { Institute of Mediation, 2013). }\end{array}$ & \\
\hline $\begin{array}{l}\text { 3. Inconsistency of } \\
\text { terms of mediation, } \\
\text { established by the } \\
\text { law on mediation, } \\
\text { and terms of } \\
\text { proceedings in } \\
\text { courts of General } \\
\text { jurisdiction, } \\
\text { established by } \\
\text { procedural law }\end{array}$ & $\begin{array}{l}\text { Harmonization of rules on the timing } \\
\text { of mediation and rules on the terms of } \\
\text { consideration of the case, established } \\
\text { by the agribusiness code and the RF } \\
\text { GPK (in in particular exceptions of } \\
\text { term of carrying out the mediation of } \\
\text { the General terms of the races review } \\
\text { of cases in courts of General } \\
\text { jurisdiction, or suspension of civil } \\
\text { proceedings for the period of } \\
\text { mediation (Kalashnikova, 2010). }\end{array}$ & $\begin{array}{l}\text { Absence of risk of } \\
\text { violation of terms of } \\
\text { consideration of cases. }\end{array}$ \\
\hline $\begin{array}{l}\text { 4. The use of } \\
\text { arbitration } \\
\text { (arbitration } \\
\text { proceedings) in the } \\
\text { case of a mediation } \\
\text { clause. }\end{array}$ & $\begin{array}{l}\text { Legal regulation of the validity and } \\
\text { significance of a mediation clause for } \\
\text { the arbitral Tribunal. Making relevant } \\
\text { changes in the legislation on trade } \\
\text { Teya courts, which would be by far } \\
\text { the mouth was naveivali the } \\
\text { implications mediative and arbitration } \\
\text { clause in the text of the Treaty parties, } \\
\text { as well as determine the possible } \\
\text { dates the power of the arbitrator, } \\
\text { which can be taken threads to ensure } \\
\text { the implementation of the mediation- } \\
\text { reservations (Shvabauer, 2015). }\end{array}$ & $\begin{array}{l}\text { The presence of a } \\
\text { mediation clause will not } \\
\text { limit the use of arbitration, } \\
\text { and arbitration does not } \\
\text { deprive the parties of the } \\
\text { right to use mediation. }\end{array}$ \\
\hline $\begin{array}{l}\text { 5. Ambiguity as to } \\
\text { the requirements } \\
\text { for an agreement } \\
\text { on mediation. }\end{array}$ & $\begin{array}{l}\text { Introduction into the law on } \\
\text { mediation of instructions on the need } \\
\text { for the mediator to sign documents in } \\
\text { connection with the procedure } \\
\text { mediations. }\end{array}$ & $\begin{array}{l}\text { Regulation of the } \\
\text { mediation procedure. }\end{array}$ \\
\hline $\begin{array}{l}\text { 6. In the law on } \\
\text { mediation there are } \\
\text { no mandatory the } \\
\text { rules rules of } \\
\text { procedure of the } \\
\text { mediation. The } \\
\text { mediation } \\
\text { procedure is } \\
\text { possible on non- } \\
\text { professional basis } \\
\text { (Sitdikova } \text { et al., } \\
\text { 2017). }\end{array}$ & $\begin{array}{l}\text { To develop standard or recommended } \\
\text { rules for conducting mediation } \\
\text { procedures authorized by the } \\
\text { mediators. }\end{array}$ & $\begin{array}{l}\text { Legal regulation of } \\
\text { mediation procedures. }\end{array}$ \\
\hline
\end{tabular}




\begin{tabular}{|c|c|c|}
\hline $\begin{array}{l}\text { 7. The law on } \\
\text { mediation does not } \\
\text { establish the } \\
\text { necessity of } \\
\text { obtaining by the } \\
\text { parties of the } \\
\text { qualified legal } \\
\text { assistance in } \\
\text { mediation } \\
\text { procedure. }\end{array}$ & $\begin{array}{l}\text { Informing the parties by the mediator } \\
\text { about the need to obtain legal } \\
\text { assistance before signing any } \\
\text { agreements. }\end{array}$ & $\begin{array}{l}\text { Giving binding force to the } \\
\text { code of professional ethics } \\
\text { for all mediators } \\
\text { (Lukyanivska, 2017). }\end{array}$ \\
\hline $\begin{array}{l}\text { 8. Unclear legal } \\
\text { regulation of the } \\
\text { rules of disclosure } \\
\text { of confidential } \\
\text { information by the } \\
\text { mediator. }\end{array}$ & $\begin{array}{l}\text { Amend the rules on the obligation of } \\
\text { the mediator to respect the } \\
\text { confidentiality of information that } \\
\text { has become known in connection } \\
\text { with the mediation (Reshetnikova, } \\
\text { 2016). }\end{array}$ & $\begin{array}{l}\text { Safeguards to ensure } \\
\text { confidentiality. }\end{array}$ \\
\hline $\begin{array}{l}\text { 9. Mixing of the } \\
\text { mediation and } \\
\text { settlement } \\
\text { agreements } \\
\text { manifests itself in } \\
\text { case Pro } \\
\text { conducting the } \\
\text { mediation } \\
\text { procedure after the } \\
\text { beginning of the } \\
\text { trial (Semikin and } \\
\text { Yusupova, 2017). }\end{array}$ & $\begin{array}{l}\text { The legislative establishment that the } \\
\text { conclusion of a mediation agreement } \\
\text { becomes an independent basis for the } \\
\text { termination of the proceedings with } \\
\text { the determination of the court on the } \\
\text { approval of the mediation agreement. }\end{array}$ & $\begin{array}{l}\text { Approval of the mediation } \\
\text { agreement by the court. }\end{array}$ \\
\hline $\begin{array}{l}10 \text {. The law on } \\
\text { mediation indicates } \\
\text { only one option of } \\
\text { termination of } \\
\text { mediation in case } \\
\text { of dispute } \\
\text { settlement- } \\
\text { mediation the } \\
\text { agreement, which } \\
\text { in settlement case } \\
\text { dispute without } \\
\text { transfer to court is } \\
\text { civil- legal } \\
\text { transaction. }\end{array}$ & $\begin{array}{l}\text { The Law specifies the possibility of } \\
\text { completing a mediation or a } \\
\text { mediation separate meeting by } \\
\text { signing the minutes of the meeting by } \\
\text { the mediator, as well as the fact that } \\
\text { the mediation agreement concluded as } \\
\text { a result of mediation may be both a } \\
\text { civil transaction and not binding and } \\
\text { may be the basis for subsequent } \\
\text { agreements and actions of the parties. }\end{array}$ & $\begin{array}{l}\text { A mediation agreement } \\
\text { concluded as a result of } \\
\text { mediation may or may not } \\
\text { constitute a civil } \\
\text { transaction and may be the } \\
\text { basis for subsequent } \\
\text { contracts and actions of } \\
\text { the parties (Karpenko and } \\
\text { Osinovskaya, 2017). }\end{array}$ \\
\hline $\begin{array}{l}11 . \text { The absence of } \\
\text { enforcement of the } \\
\text { mediation } \\
\text { agreement. The } \\
\text { lack of information } \\
\text { about mediators }\end{array}$ & $\begin{array}{l}\text { To provide for certain procedural } \\
\text { actions of the parties that must be } \\
\text { committed after completion of the } \\
\text { procedure mediation (Bulletin of the } \\
\text { Federal Institute of Mediation, 2017). }\end{array}$ & $\begin{array}{l}\text { The increase in the } \\
\text { number of } \\
\text { applications to } \\
\text { mediation at the stage } \\
\text { choice of dispute } \\
\text { settlement method. }\end{array}$ \\
\hline
\end{tabular}




\begin{tabular}{|c|c|c|}
\hline $\begin{array}{l}\text { 12. The lack of } \\
\text { information about } \\
\text { mediators }\end{array}$ & $\begin{array}{l}\text { The establishment of the Law on } \\
\text { mediation standards as to how the or } \\
\text { information about mediators and } \\
\text { organizations-providers of mediation } \\
\text { services can be collected, checked } \\
\text { and disseminated to the citizens in the } \\
\text { Russian courts they had a sufficient } \\
\text { degree of awareness about the } \\
\text { presence of mediators (Nosyreva and } \\
\text { Filchenko, 2012). }\end{array}$ & $\begin{array}{l}\text { Awareness of all } \\
\text { stakeholders. }\end{array}$ \\
\hline $\begin{array}{l}\text { 13. The Absence in } \\
\text { the law on } \\
\text { mediation of an } \\
\text { exact wording on } \\
\text { vocational } \\
\text { education of a } \\
\text { mediator }\end{array}$ & $\begin{array}{l}\text { Amendments to the law on mediation } \\
\text { regarding the introduction of rules on } \\
\text { accreditation/certification, registers of } \\
\text { mediators. Creation of quality control } \\
\text { of professional mediation services on } \\
\text { the basis of the accepted professional } \\
\text { standard on mediation. }\end{array}$ & $\begin{array}{l}\text { Suspension, termination of } \\
\text { accreditation/certification, } \\
\text { exclusion from the register } \\
\text { of incompetent mediators. }\end{array}$ \\
\hline
\end{tabular}

\section{Conclusions}

It follows from the Table that there are no insurmountable obstacles, but there are problems that need to be solved and that are already being solved. First of all, mediation, like any other new institution in our country, required a clear designation in the legal field, required legitimation by the state. After all, in our society there is a justified caution to all new trends and experiments. That is why the adoption of the law on mediation and a number of other steps that demonstrated the long-term interest of the state in this institution was simply necessary (Fedorenko et al., 2017).

On the basis of the Federal law "on alternative dispute settlement procedure with the participation of a mediator (mediation procedure)" dated 27.07.2010, the principles of business mediation include confidentiality, respect for equality of mediation parties, professionalism, impartiality, independence, efficiency, long-term partnership and trust (The Federal law on alternative procedure of settlement of disputes with participation of the intermediary mediation procedure, 2010).

A.V. Korobkin defines the principles of mediation as follows: "a third party should be independent and not be dependent or subordinate to one of the parties to the conflict, as well as be able to make fair judgments, not have prejudice against the parties (one or both) and the subject matter of the dispute" (Korobkin, 2011). S.I. Kalashnikova argues that the mediator has no right to draw conclusions regarding any disputed matter and to make advisory decisions (Kalashnikova, 2011). O.V. Allahverdova believes that professional mediators have a rule; to participate in the process without any prejudice. She believes that all feelings should be left outside the mediation procedure, if you realize that it is difficult for you to maintain impartiality, you need to stop participating in the procedure (Allahverdov, 2006). 
However, the Law does not contain important legal requirements (mandatory) in our opinion to the legal justification of the content (text) of the mediation agreement, which is sent to the court for approval already in the form of a settlement agreement, the law on mediation does not contain that, in our opinion, may be the subject of discussion and, possibly, with the subsequent introduction of appropriate amendments to the law on mediation (Shabalina, 2016; Fomina, 2016).

Moreover, the absence of cases of non-compliance with procedural conditions contained in mediation agreements is noted as a positive point (Certificate of practice of application by courts of the Federal law, 2015). As a result of this study, the authors believe that effective resolution through mediation of conflicts and disputes in the business environment is particularly important. In particular, those that arise in connection with non-performance or improper performance of contractual obligations, as well as disputes in the field of management.

\section{Results and discussion}

Mediation has proved to be effective when considering disputes between individuals, between legal entities and in mixed disputes, between legal entities and individuals, as well as in disputes between individuals and legal entities on the one hand, and state and municipal authorities on the other. Mediation is a qualitatively different approach to the resolution of business disputes, and that is its special value.

The special interest of the parties to the dispute in mediation is manifested when the main issue in the dispute is not legal claims, but the current interests of the partners and the opportunity to continue and develop business cooperation. The advantages of mediation are fully manifested in cases where it is necessary to develop a comprehensive agreement of the parties to the dispute on a set of issues, while the legal dispute covers only part of the problem. This situation is most characteristic of corporate conflicts. Mediation is a mutually beneficial resolution of conflicts in business.

Mediation is negotiations with the participation of a neutral mediator (mediator), who is only interested in ensuring that the parties to the dispute reach a mutually beneficial solution to their current issues and problems. In Russia, mediation is regulated by Federal law No. 193-FZ of 2010 "on alternative dispute settlement procedure with the participation of an intermediary (mediation procedure)". The authors fully agree with the report of the Supreme court judge Natalia Pavlova that entrepreneurs and ordinary citizens of our country are interested in quick and effective dispute resolution at once. She stressed that in practice justice is not always a speedy one; "the Court must be painstakingly aware of disputable situations, and sometimes it takes a long time". However, the parties to the proceedings were well aware of the details of their conflict and could resolve it without mandatory coercion. What is needed, is the Institute of Judicial Conciliation, said the Rapporteur. According to her, this tool saves forces and means of all participants of 
business; "This Institute isn't new for our country and acted in the Russian Empire therefore it is mistaken to claim that such way of search of the world not in our mentality" (Shabalina, 2016). So, the advantages of mediation in business are:

$\checkmark$ saving time (preparation for mediation takes no more than a week, and the process itself, as a rule, no more than three hours);

$\checkmark$ saving money and resources (thanks to the speed of the process, mediation saves costs and constantly increasing if the business is in conflict, as well as avoids legal costs);

$\checkmark$ preservation of good reputation (due to the confidentiality of mediation, it is excluded that the information that the company is in conflict, in the press and on the websites of the courts);

$\checkmark$ independence in decision-making (in mediation decisions are made by the participants themselves with the assistance of a specially trained mediator-in other words, whether the decision will be enforceable and beneficial for the parties depends on them themselves, and not on the higher authority that makes the decision);

$\checkmark$ preservation and building of partnership relations (successfully conducted mediation contributes to the establishment of relations between the parties, in the course of decision-making to overcome the conflict are born business ideas that give a serious impetus to mutually beneficial cooperation and development).

It should be concluded that it is profitable to turn to a business mediator:

- when it is important to resolve the conflict as soon as possible;

- when it is important to make a decision on how to resolve the conflict;

- when the conflict can spoil the reputation of the company;

- when conflict threatens important partnerships;

- when judicial perspective confusing and ambiguous;

- when the conflict is not exhausted by the legal field and affects personal interaction;

- when the conflict is beyond the competence of the authorities;

- when value and cultural factors are involved in the conflict.

V.V. Blazheev called mediation as "one of the most interesting new directions in jurisprudence, received legislative consolidation" (Blazheev, 2008). V.M. Platonov said that "our judicial system is not as expensive and long as in the West. And this circumstance hinders the development of mediation" (Platonov, 2015). By virtue of article 34 of the Civil procedure code and article 41 of the Arbitration procedural code of the Russian Federation the number of persons involved in the case, the mediator is not the case, which deprives him of the right to familiarization with the case materials (The civil procedural code of the Russian Federation, 2002). We believe it is possible to grant the mediator the right to familiarize with the case file in order to obtain full information about the circumstances of the dispute. Currently, in order to improve the efficiency of enforcement of court decisions, the Ministry of 
Justice of the Russian Federation is developing a long - term program for the period up to 2020 (Sitko, 2016).

\section{Conclusion}

In conclusion, it should be noted that mediation for business has several features. It has less emotional intensity of the parties during the procedure, more pronounced material interest, limited time. The business has higher privacy requirements. The possibility of abuse of the rights by the parties should not be discounted. It is known that in the developed countries of the West there is much more than we have, the number of dispute resolution mechanisms and conflicts arising from many types of relations related to doing business. Mediation there is not in last place.

It makes it possible to find a way out of the created, unsolvable at first glance, to try not only to share the existing values, but also to create new ones, as well as to protect business through confidentiality. Winning time and the possibility to continue the cooperation, keeping the good name of their firms, entrepreneurs carry the mediation and their personal relationship by inviting a professional mediator to resolve conflict situations not directly related to the business, but the impact on the psyche of the businessman. Today for firms seeking to enter the international market, and reputational risks in connection with the judicial process is very painful. Mediation procedures help to reduce these risks to a minimum.

\section{References:}

Allahverdov, V.O. 2006. School of mediation (mediation) in Arbitration, 2.

Blazheev, V. 2008. We need a culture of out-of-court dispute resolution, 2(8), 10-15.

Bulletin of the Federal Institute of mediation. 2013. Scientific Red TSA Shamlikashvili. Moscow, Interregional center of management and political consulting, 119.

Bulletin of the Federal Institute of Mediation. 2013. Scientific Red TSA Shamlikashvili. Moscow, Interregional center for management and political consulting, 26.

Bulletin of the Federal Institute of Mediation. 2017. Scientific Red TSA Shamlikashvili. Moscow, Interregional center for management and political consulting, 18.

Certificate of practice of application by courts of the Federal law. 2015. On alternative procedure of settlement of disputes with participation of the intermediary (mediation procedure)», UTV, Presidium of the Supreme Court of the Russian Federation for the period from 2013 to 2014. Bulletin of the Supreme Court of the Russian Federation, 6 .

Certificate of practice of application by Courts of the Federal Law. 2010. On alternative procedure of settlement of disputes with participation of the intermediary (mediation procedure). UTV, Presidium of the Supreme Court of the Russian Federation for the period from 2016 to 2017. Bulletin of the Supreme Court of the Russian Federation, No. 6.

Emelkina, A.I. 2016. Problems of Improving Russian Legislation on Property Rights and Other Proprietary Interests. European Research Studies Journal, 19(3) Part B, 170186. 
Fedorenko, N.I., Fatykhova, E.M., Dzyuba, L.M. 2017. Actual problems of alternative dispute resolution through mediation and put their solution. Science and education: economy; enterprise; law and management, 2(81), 107.

Fomina, Yu.L. 2016. Protection of the Right to Respect for Private and Family Life in European Court of Human Rights. European Research Studies Journal, 19(3) Part B, 97-110.

Kalashnikova, S.I. 2011. Mediation in the sphere of civil jurisdiction. M. Intronic-Media, 304.

Kalashnikova, S.I. 2010. Mediation in the sphere of civil Jurisdiction: Abstract of the dissertation, K.Yu.H. Yekaterinburg.

Karpenko, A.D., Osinovskaya, A.D. 2017. Mediation. Library Journal Arbitration, 4.

Korobkin, A.V. 2011. Concepts and principles of civil mediation. Man: Crime and punishment, 3, 140-143.

Lukyanivska, O.V. 2017. Mediation in Russia: first results and future prospects. Rossiskaja, $3,15$.

Maslennikova, L.V., Telesheva, Yu.A. 2017. Mediation Institute in the Russian Federation: problems and prospects. Young scientist, 13, 462-464.

Nosyreva, E.I., Filchenko, D.G. 2012.The development of mediation in Russia: theory, practice, education. Moscow, Infotropic Media.

Pavlova, J. 2018. Supreme Court of the Russian Federation at the meeting of the Plenum of the Supreme Court.

Platonov, V.M. 2015. Performance. The first all-Russian conference of mediators. Mediation: theory, practice, development prospects. Organized by the Federal Institute of Mediation (FIM) in cooperation with the Moscow State University.

Reference of the Presidium of the Supreme Court of the Russian Federation. 2017. On the practice of the Courts of the Federal law № 193-FZ, On alternative dispute settlement procedure involving a mediator (mediation procedure for the period from 2016 to 2017 ).

Reshetnikova, O.N. 2016. Application of restorative justice and mediation technologies in dispute and conflict resolution practice in local communities. Local rights, 3, 91-94.

Romanova, N. 2017. Review of materials of the international scientific and practical conference "Prospects of formation and development of mediation in the regions", December 7.

Shvabauer, N. 2015. Agree. Summed up the results of the experiment on mediation in conflict resolution. Rossiyskaya Biznes-Gazeta. No. 735 (2).

Sitdikova, L.B., Shilovskaya, A.L., Nadine, I.N. 2017. Democratization of civil-procedural legislation by strengthening conciliation procedures. Business in law, 3, 14 .

Semikin, S.A., Yusupova, A.N. 2017. Conciliation procedures in the context of comparative analysis of the procedural legislation of Russia and other States. Bulletin of the Saratov State Law Academy, 4.

Shabalina, E.A. 2016. Alternative dispute resolution in form of mediation: the experience of the United States. Competitive right, 4.

Sitko, N.G. 2016. Mediation in modern Russia. Law: history, theory, practice: materials of the IV mezhdunar science. Conference Saint-Petersburg, URL https://moluch.ru/conf/law/archive/182/10728.

The Federal law on alternative procedure of settlement of disputes with participation of the intermediary (mediation procedure). 2010. N 193-FZ (last edition).

The civil procedural code of the Russian Federation. 2002. N 138-FZ, The arbitration procedural code of the Russian Federation, N 95-FZ. 